\title{
URGENSI STRATEGI PROMOSI DAN MODEL UPZM DALAM UPAYA MENGGALI POTENSI ZAKAT DI ACEH
}

\author{
Safwan Kamal S.EI, M.EI \\ Dosen Institut Agama Islam Negeri Langsa \\ e-mail: Uin.safwan@yahoo.com
}

\begin{abstract}
Abstrak
Proses penghimpunan zakat (funding) di Provinsi Aceh jika ditinjau dari persentase potensi zakat yang ada masih belum mencapai hasil yang memuaskan, Baitul Mal haruslah melakukan promosi dan sosialisasi secara ektra serta melakukan strategi jemput bola untuk menarik potensi zakat yang besar di Provinsi Aceh. Untuk membantu berjalannya roda zakat di Aceh, maka Baitul Mal harus serius menangani proses pengumpulan zakat dengan memperbanyak sumber daya pengumpul zakat (fundrising), membentuk tim promosi dan sosialisasi, adapun salah satu gagasan strategi yang penulis tawarkan untuk menggali potensi zakat di Aceh yaitu dengan upaya pengaktifan unit pengumpul zakat Masjid (UPZM). Dengan penerapan aplikasi promosi, sosialisasi dan pengaktifan UPMZ sebagai salah satu upaya untuk menguatkan manajemen pengumpulan zakat di Aceh sangat dimungkinkan penerimaan zakat di Aceh meningkat dan manfaat zakat dapat dirasakan secara lebih luas dan memiliki kuantitas baik.
\end{abstract}

Kata Kunci: Promosi, UPMZ, Potensi Zakat

\section{PENDAHULUAN}

Islam sebagai agama "Rahmatallila'lamin" menawarkan lima pilar penting yaitu syahadat, shalat, puasa, zakat dan haji. Lima pilar ini merupakan hal wajib bagi setiap muslim untuk membangun tumpukan amal dari kegiatan vertikal dan horizontalnya selama didunia. Pilar zakat merupakan pilar yang sangat menonjol dalam sisi penyokong ekonomi umat. Sebab zakat adalah ibadah maaliyyah ijtima'iyyah yang memiliki posisi sangat penting, strategis, dan menentukan (Yusuf al-Qaradhawi,1993: 235) Perhatian Islam terhadap pemberdayaan ekonomi sangatlah besar, instrumen zakat adalah salah satu upaya membentuk nurani setiap muslim untuk senantiasa bersikap dan bertindak sosial, dengan lahirnya pribadi-pribadi yang peka terhadap setiap kondisi umat, maka Islam sebagai rahmatallila'lamin akan terwujud dalam kehidupan sehari-hari.

Peran zakat dalam mengentaskan kemiskinan adalah peran yang tidak bisa dipungkiri keberadaannya, meski demikian zakat sebenarnya lebih dari sekedar mengatasi kemiskinan tetapi juga mampu mengatasi permasalahan-permasalahan kemasyarakatan 
lainnya. Termasuk masalah yang ada dalam tubuh orang Islam itu sendiri, sebagaimana membantu negara muslim lainnya dalam menegakkan kalimatullah, dan memotivasi orang kaya berhutang untuk dapat berbuat baik serta membuatnya istiqamah dalam kebaikan. (Yusuf Qaradhawi, 2005: 30)

Di dalam Al-Qur'an terdapat dua puluh tujuh ayat yang mensejajarkan antara shalat dengan kewajiban zakat dalam berbagai bentuk kata. (Yusuf Al-Qaradhawi, 1991: 42) Bahkan sebagian Ulama berpendapat bahwa terdapat delapan puluh ayat yang mensejajarkan kewajiban shalat dengan kewajiban zakat. (Sayyid Sabiq, 1968: 683) Dan dalam beberapa ayat Al-Qur'an jelas pula di terangkan mengenai reward bagi mereka yang sungguh-sungguh menunaikan zakatnya dan punishment bagi mereka yang sungguh-sunguh meninggalkan dan tidak mau menunaikannya. Hakikat pentingnya zakat pernah ditekankan oleh Abu Bakar Ash-Shiddiq terhadap sebagian kelompok muslim yang enggan membayar zakat setelah wafanya Nabi Muhammad SAW. Mereka merasa bahwa yang berhak memungut zakat hanya Nabi, hal ini memicu tindakan Abu Bakkar sebagai Khalifah untuk memerangi keras orang yang enggan membayar zakat meskipun ia menunaikan shalat.

Zakat adalah sebuah solusi untuk mengatur distribusi kekayaan manusia agar tidak terjadi kesenjangan antara orang miskin dan orang kaya. Dalam surat Al-Hasyr Allah berfirman “.....Agar harta itu jangan hanya beredar di antara orang-orang kaya saja diantara kamu. Apa yang diberikan Rasul padamu maka terimalah. Dan apa yang dilarangnya bagimu maka tinggalkanlah. Dan bertakwalah kepada Allah. Sungguh, Allah sangat keras hukumannya" ( Q.S. Al-Hasyr : 7). Ayat tersebut menunjukkan bahwa Islam turut memerintahkan manusia untuk menghidupkan perekonomian dan menghindari terjadinya pemupukan harta dipihak orang-orang tertentu saja. Islam sangat memahami bahwa sifat manusia yang cendrung suka dan mencintai harta.

Oleh sebab itu, untuk mengantisipasi terjadinya pemanfaatan harta pada pribadi atau kelompok tertentu saja sehingga terjadinya keterbatasan pemanfaatan harta terutama bagi lapisan masyarakat bawah, maka Islam mencekal orang-orang yang suka menumpuk-numpukkan harta dengan ancaman: "Dan orang-orang yang menyimpan emas dan perak, dan tidak menafkahkannya pada jalan Allah, maka beritahukanlah kepada mereka, (bahwa mereka akan mendapat) siksa yang pedih, pada hari dipanaskan emas perak itu dalam neraka Jahannam, lalu dibakar dengannya dahi mereka, lambung dan punggung mereka (lalu dikatakan) kepada mereka: "Inilah harta bendamu yang kamu simpan untuk dirimu sendiri, maka rasakanlah sekarang (akibat dari) apa yang kamu simpan itu"(Q.S. At-Taubah 34-35). 
Pada dasarnya Islam tidak melarang seseorang memiliki kekayaan sebanyak apapun, Nabi Muhammad dan para sahabat seperti Abu Bakar, Umar, Utsman dan Abdurrahman bin Auf merupakan para saudagar-saudagar Islam yang memiliki kekayaan yang begitu besar. Dan mereka sukses membuktikan bahwa kekayaan yang mereka miliki tidak digunakan untuk menumpuk-numpukkan harta tetapi dikelompokkan menjadi tiga bagian yang jauh dari sifat menumpuk-numpuk harta yaitu, investasi, Shadaqah, Zakat, dan untuk kebutuhan hidup mereka dan keluarganya yang penuh kesederhanaan. Poin penting yang diajarkan oleh mereka adalah setiap muslim harus kaya tetapi tidak memperkaya diri dan sombong dengan kekayaannya.

Salah satu penyebab belum berfungsinya zakat sebagai instrument distribusi kekayaan yang efektif adalah belum terkumpulnya zakat secara optimal di lembaga-lembaga pengumpul zakat Khususnya Baitul Mal yang berada di Provinsi Aceh. Hal ini didasari oleh banyaknya masyarakat yang belum mengetahui apa itu zakat mal? Mengapa harus di bayar? Kapan harus dibayar? Dan dimana harus dibayar? Dan berapa jumlah yang harus dibayar? Serta bagaimana cara membayar zakat agar lebih maslahah? Berbagai pertanyaan muncul dikalangan masyarakat yang minim pengetahuan tentang kewajiban berzakat mal. Sebenarnya Istilah "zakat mal” sudah sangat mendarah daging dikalangan umat Islam khususnya di Aceh. Tetapi aplikasi zakat justru menjadi titik berat termarjinalnya kewajiban zakat yang berbeda dengan kewajiban sholat.

Tidak dipungkiri bahwa edukasi perintah sholat telah diterapkan orang tua kepada anak-anaknya sejak usia dini dan pada mereka diberikan sanksi jika telah berumur 10 tahun tetapi tidak mau mengerjakan sholat. Berbedahalnya dengan perintah zakat yang memang baru dikenal ketika mereka memasuki tahap pendidikan di sekolah dan itupun hanya pengenalan saja dan belum pada tahap peraktik. Hal ini tentu menjadi tugas penting para Amil dan kita semua untuk senantiasa menanamkan edukasi zakat yang bisa saja dimulai dengan edukasi infaq dan shadaqah bagi generasi-generasi muslim serta menggemakan kewajiban berzakat pada kaum muslimin ketika mereka dewasa. Dengan pendekatan kualitatif yang berbasis pada pemahaman pustaka (library research). Penelitian ini berupaya menggiring sebuah konsep promosi dan pengumpulan zakat melalui teknik UPZM (unit pengumpul zakat masjid).

\section{PEMBAHASAN}

\section{Pengertian Zakat}

Menurut Wahidi kata dasar dari zakat adalah "Zaka" yang berarti bertambah atau tumbuh, sehingga dapat dikatakan, tanaman itu zaka, artinya tumbuh, sedangkan tiap sesuatu yang bertambah disebut zaka artinya bertambah. Bila satu tanaman 
tumbuh tanpa cacat, maka kata zaka di sini berarti bersih.

Zakat dari segi istilah fikih bererti "Sejumlah harta tertentu yang diwajibkan Allah diserahkan kepada orang-orang yang berhak" disamping berarti “mengeluarkan jumlah tertentu itu sendiri".

Ibnu Taimiyah berkata, " Jiwa orang yang berzakat itu menjadi bersih dan kekayaannya akan bersih pula, bersih dan bertambah maknanya "tumbuh" dan "suci" bukan hanya dipakai untuk kekayaan saja, tetapi lebih dari pada itu, zakat juga berfungsi untuk jiwa orang yang menzakatkannya, sesuai dengan firman Allah SWT:

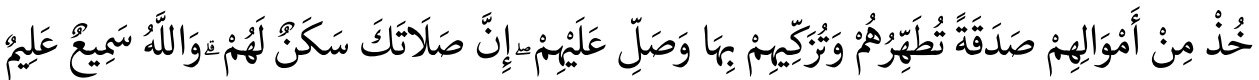

Artinya : "Ambillah zakat dari sebagian harta mereka, dengan zakat itu kamu membersihkan dan mensucikan mereka dan mendoalah untuk mereka. Sesungguhnya doa kamu itu (menjadi) ketenteraman jiwa bagi mereka. dan Allah Maha mendengar lagi Maha mengetahui" (Q.S.At-Taubah: 103)

Zakat menurut syara' adalah hak yang wajib pada harta. Malikiyah memberikan definisi bahwa zakat adalah mengeluarkan sebagian tertentu dari harta tertentu yang telah sampai nishab kepada orang yang berhak menerima, jika kepemilikan, haul (genap satu tahun) telah sempurna selain barang tambang, tanaman dan harta temuan. Hanafiyah mendefinisikan bahwa zakat adalah pemberian hak kepemilikan atas sebagian harta tertentu kepada orang tertentu yang telah ditentukan oleh syari'at, semata-mata karena Allah. Syafi'iyah memberikan definisi bahwa zakat adalah nama untuk barang yang dikeluarkan untuk harta atau badan (diri manusia untuk zakat fitrah) kepada pihak tertentu. Definisi zakat menurut Hanabilah adalah hak yang wajib pada harta tertentu kepada kelompok tertentu pada waktu tertentu (Wahbah Az Zuhaili, 2011: 164-165).

\section{Hikmah Zakat}

Instrumen zakat merupakan fardhu yang amat penting untuk ditunaikan oleh setiap Muslim yang mampu. Sebab dalam sisi kehidupan dunia Allah memang telah melebihkan manusia dalam satu sisi tetapi Allah juga yang mengatur pola untuk menutupi kekurangan manusia dari sisi yang lain. Pola inilah menjadi pokok ajaran Islam agar kehidupan setiap manusia dapat terpenuhi dengan baik. Ada beberapa Hikmah zakat yang secara umum langsung teraplikasi dalam kehidupan. Pertama, menjaga dan membentengi harta dari penglihatan atau jangkauan tangan-tangan pendosa dan pelaku kejahatan. Kedua, menolong orang-orang fakir dan orang-orang yang membutuhkan. Zakat bisa membimbing tangan mereka untuk memulai pekerjaan dan kegiatan jika mereka mampu dalam hal ini. Zakat juga dapat menolong mereka untuk 
menuju situasi kehidupan yang mulia jika mereka lemah. Zakat melindungi masyarakat dari penyakit fakir, melindungi negara dari ketidak mampuan dan kelemahan dengan cara kelompok masyarakat bertanggung jawab akan jaminan terhadap orang-orang fakir dan kebutuhan mereka. Sesuai dengan firman Allah:

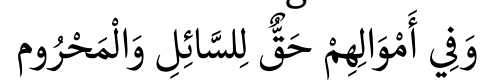

"dan pada harta-harta mereka ada hak untuk orang miskin yang meminta dan orang miskin yang tidak mendapat bagian". (QS. Adz-Zaariyaat : 19)

Ketiga, zakat dapat menyucikan diri dari penyakit kikir dan bakhil, membiasakan orang mukmin untuk memberi dan dermawan. Keempat, mengharuskan untuk bersyukur terhadap nikmat harta. (Wahbah Az Zuhaili, 2011: 166-167).

Menurut Hasbi, zakat memiliki tiga belas rahasia bagi yang memberi yaitu:

1. Mensucikan para mukmin dari penyakit bakhil yang menjadi penghalang bagi keberuntungan dan membiasakan para mukmin bersifat murah tangan yang membawa kepada keberuntungan

2. Mendekatkan para mukmin kepada Allah dan menimbulkan perasaan bahwa kebahagiaan itu adalah dapat mengeluarkan harta dijalan Allah

3. Membawa para mukmin menepati tauhidnya dan tasyahudnya

4. Membawa para mukmin mensyukuri Tuhan yang telah memelihara dari meminta-minta dan memberi harta yang banyak kepadanya.

5. Menghindari jalan yang gelap yang tidak berujung dan menggariskan tujuan hidup untuk mencari keridhaan Allah

6. Menyedikitkan kecurangan yang membawa pada kesesatan

7. Berperangai dengan perangai Allah, yaitu mencurahkan kebajikan dan rahmat kepada sesame manusia.

8. Memelihara diri jatuh ke lembah kikir yang merugikan

9. Memindahkan orang yang menerima nikmat itu kederajat yang lebih baik yaitu derajat mencukupi sesuatu, kederajat tidak membutuhkan sesuatu

10. Memelihara harta dari hilang percuma

11. Membentengkan diri dari binasa.

12. Menolak bencana kemelaratan

13. Melaksanakan kewajiban.

\section{Pengertian Pengelolaan zakat}

Undang-undang Nomor 38 Tahun 1999 tentang pengelolaan zakat dan keputusan mentri Agama Republik Indonesia Nomor 581 Tahun 1999 tentang pelaksanaan Undang-undang Nomor 38 Tahun 1999 tentang pengelolaan zakat menerangkan bahwa : 
Pengelolaan zakat adalah kegiatan perencanaan dan pengawasan terhadap pengumpulan dan pendistribusian serta pendayagunaan zakat (Pasal 1 Ayat (1)). Muzakki adalah orang atau badan yang dimiliki oleh orang muslim yang berkewaiban menunaikan zakat ( Pasal 1 ayat (3)) Mustahik adalah orang atau badan yang berhak menerima zakat (Pasal 1 ayat(4)).

\section{Azas dan Tujuan Pengelolaan Zakat}

Salah satu tujuan pengelolaan zakat secara professional yaitu dimaksudkan agar sumberdana zakat yang terkumpul dapat dimanfaatkan bagi kesejahteraan masyarakat. Dalam hal ini pemerintah berkwajiban memberikan perlindungan, pembinaan dan pelayanan kepada muzakki, mustahik dan pengelola zakat. Untuk maksud tersebut, maka dalam pengelolaan zakat tersebut harus berdasarkan iman dan taqwa agar dapat mewujudkan keadilan sosial, kemaslahatan, keterbukaan dan kepastian hukum sesuai jiwa pancasila dan Undang-undang Dasar 1945 (Pasal 4)( Safwan Idris,1997: 27.

Adapun tujuan dari pengelolaan zakat yaitu:

1. Meningkatkan kesadaran masyarakat dalam penunaian dan dalam pelayanan ibadah zakat sesuai dengan tuntutan agama.

2. Meningkatkan fungsi dan peranan pranata keagamaan dalam upaya mewujudkan kesejahteraan masyarakat dan keadilan sosial.

3. Meningkatkan hasil guna dan daya guna zakat( Pasal 5).

\section{Badan/Lembaga pengelolaan Zakat}

Dalam upaya mengembangkan pengumpulan zakat di era modern, Badan/ Lembaga zakat sangat berperan penting sebagai sentral pengumpulan zakat serta dapat mengcover kebutuhan dan tujuan distribusi zakat. Dalam Surat At Taubah ayat 60 dijelaskan bahwa salah satu bagian yang berhak menerima zakat adalah mereka para amil (a'milina alaiha). Ayat ini menjelaskan bahwa para amil memiliki urgensi yang sangat penting dan diberi kewajiban dan hak khusus oleh Allah SWT. Artinya mereka harus berjuang dalam upaya menghimpun zakat baik dalam kontek menuliskan, mensosialisasi, menghitung dan sebagainya yang terkait dengan pengelolaan zakat di era modern. Sejarah Amil sudah pernah di praktekkan langsung di zaman Nabi Muhammad SAW ketika nabi mempekerjakan seorang pemuda dari suku Asad, yang bernama Ibnu Lutaibah untuk mengurus zakat bani Sulaim. Pernah pula mengutus Ali bin Abi Thalib ke Yaman untuk menjadi amil zakat. Dan pengutusan Muaz bin jabal ke Yaman.(Didin Hafifuddin, 2002: 124). Demikian pula yang dilakukan oleh khulafaurrasyidin dan khalifah setelahnya hingga saat ini. 
Saat ini, proses pemungutan zakat terus berkembang khususnya di tanah air. Badan Amil Zakat Nasional (BAZNAS) yang berkedudukan di Ibu kota Negara dibentuk oleh presiden atas usul menteri, sedangkan Badan Amil Zakat Daerah (BAZDA) berkedudukan di ibu kota Provinsi, Kabupaten dan Kecamatan dibentuk oleh Gubernur, Bupati/ Walikota dan camat atas usul kepala kantor Departemen Agama setempat. Di setiap kelurahan dan desa dapat di bentuk unit pengumpul zakat (UPZ) oleh BAZ Kecamatan. Demikian pula BAZNAS dan BAZDA yang lain dapat dibentuk UPZ di instansi Pemerintah dan swasta sesuai dengan tingkatannya dan sesuai dengan kebutuhan. Susunan dan tata kerja BAZ dan UPZ diatur lebih lanjut dengan keputusan Menteri. Selain oleh BAZ, pengelolaan zakat juga dapat dilakukan oleh Lembaga Amil Zakat (LAZ) yang didirikan oleh masyarakat dan keberadaannya dikukuhkan oleh pemerintah setelah memenuhi persyaratan yang telah ditentukan (Departemen Agama RI, 2007: 154).

Khusus untuk provinsi Aceh, sesuai dengan Undang-undang Nomor 11 Tahun 2006 Tentang Pemerintahan Aceh yang diberikan Otonomi khusus oleh Pemerintah Pusat, termasuk dalam hal pengelolaan zakat. Dan qanun Aceh Nomor 10 Tahun 2007 Tentang Baitul Mal, baik Undang-undang Nomor 11 Tahun 2006 dan Qanun Nomor 10 Tahun 2007 menyebutkan bahwa:

Pasal 191 UUPA (UU Nomor 11 Tahun 2006) disebutkan bahwa zakat yang menjadi PAD tersebut (bersama-sama dengan harta agama lainnya, seperti waqaf dan infaq) dikelola oleh Baitul Mal Aceh dan Baitul Mal Kabupaten Kota.

Pasal 8 Ayat 1 Qanun Aceh Nomor 10 Tahun 2007 Tentang Ruang Lingkup Kewenangan Baitul Mal antara lain Mengurus dan mengelola zakat,waqaf dan harta agama.

Dengan demikian, pengelolaan zakat, Infaq dan shadaqah di provinsi Aceh sepenuhnya menjadi wewenang Baitul Mal Provinsi dan Kabupaten Kota serta Baitul Mal Gampong.

\section{Potensi Zakat Aceh}

Secara nyata, potensi zakat di Aceh sangat besar. Menurut Yusni Sofyan dalam waspada Online menerangkan bahwa jika berbicara soal potensi, maka zakat dan Infaq di Aceh berdasarkan perhitungan Baitul Mal Aceh mencapai angka 1 Triliyun rupiah. Menurut beliau ada beberapa sebab yang menyebabkan potensi zakat yang begitu besar tersebut belum tergali, sebab-sebab tersebut yaitu belum banyak Instansi baik Swasta maupun BUMN yang menyetor zakatnya ke Baitul Mal. Seharusnya instansi Swasta dan BUMN dan instansi vertical lainnya dapat menyetorkan zakatnya ke Bai- 
tul Mal agar kosentrasi penyaluran dapat tercapai secara maksimal khususnya faqir/ miskin yang sangat membutuhkan (www.waspada.co.id).

Salah satu kelebihan melakukan pengumpulan zakat di Baitul Mal adalah Baitul Mal dapat menyisir dan membuat peta tingkat kemiskinan di wilayah provinsi, kabupaten/ kota, kecamatan hingga pedesaan, hal ini secara massif akan mewujudkan mekanisme penyaluran yang tepat sasaran dan merata. Dengan mekanisme Baitul Mal yang ada di setiap daerah dimungkinkan untuk mengcover segala kebutuhan masyarakat khususnya di Aceh dan hal ini tidak akan terjadi jika zakat yang dimiliki oleh badan Instansi, BUMN dan lembaga lainnya atau perseorangan disalurkan secara mandiri.

\section{Optimalisasi Promosi, Sosialisasi dan UPZM}

Istilah promosi dalam dunia ekonomi sering dikenal sebagai alat pemasaran untuk memasarkan sebuah produk. Dalam dunia bisnis, promosi merupakan alat untuk mengikat konsumen untuk senantiasa menjadi salah satu bagian sebagai pembeli terhadap suatu produk.

Sebagai sebuah lembaga jasa, zakat juga melekat ruh promosi/ marketing untuk meningkatkan perolehan zakat secara optimal. Upaya menghimpun zakat juga harus menempuh instrumen pemasaran yang disebut dengan promosi. Sebab, bauran pemasaran sebagai salah satu sarana penyempaian pesan haruslah menjadi senjata yang dilakukan secara efektif, efisien dan tepat sasaran. Sebab jika bauran pemasaran tidak diarahkan pada sasaran yang tepat maka tidak akan terjadi korelasi positif dan justru merugikan. Salah satu bauran pemasaran yang sangat penting adalah promosi.

Promosi merupakan alat untuk mengkomunikasikan pesan kepada masyarakat dalam hal ini memasarkan zakat. Suatu strategi pemasaran bukanlah merupakan sejumlah tindakan khusus, tetapi lebih merupakan pernyataan yang menunjukkan usaha-usaha pemasaran pokok yang diarahkan untuk mencapai tujuan. Strategi pemasaran jasa berbeda dengan strategi pemasaran produk (Basu Swasta dan T. Hani Handoko, 1982 : 119) . Pada bauran produk hanya memiliki unsur 4P (Produk, price, promotion, dan place) sedangkan pada bauran pemasaran jasa terdiri atas $7 \mathrm{P}$, yaitu: Produk, price (harga), promotion(promosi), place (tempat), people (orang yang terlibat dalam jasa), process (bagaimana proses dalam operasi jasa) dan physical evidence ( bukti fisik ). Disamping bauran pemasaran jasa terdapat pula perbedaan karakteristik pada jasa. Istilah 'barang' dan 'jasa' adalah merupakan subkategori yang digunakan untuk menggambarkan dua jenis produk. Dalam hal ini terlepas dari istilah tersebut pada dasarnya kita ingin melihat bahwasannya bauran pemasaran penting untuk dilakukan dan diaplikasikan dalam lembaga zakat. 
Penyusunan strategi pemasaran menyangkut proses interaksi antara kekuatan pemasaran di dalam perusahaan dan keadaan diluar perusahaan. Keadaan di luar perusahaan yang utama adalah perilaku masyarakat, karena perilaku masyarakat memiliki implikasi yang amat luas terhadap perumusan strategi pemasaran. Hal ini disebabkan strategi pemasaran menyangkut dua kegiatan pemasaran yang pokok, yaitu : Pertama, pemilihan pasar yang akan dijadikan sasaran pemasaran (target market), suatu kegiatan yang memerlukan kemampuan untuk memahami perilaku masyarakat. Kedua, merumuskan dan menyusun suatu kombinasi yang tepat dari marketing mix (Basu Swasta dan T. Hani Handoko, 1982: 124).

\section{PROMOSI}

Promosi merupakan salah satu variabel marketing mix yang sangat penting dilakukan oleh perusahaan dalam pemasaran produk dan jasanya. Menurut Basu dan Irawan "Promosi adalah arus informasi atau persuasi satu arah yang dibuat untuk mengarahkan seseorang atau organisasi kepada tindakan yang dapat menciptakan adanya pertukaran dalam perusahaan."

Menurut Rambat, “Promosi merupakan salah satu variabel dalam bauran pemasaran yang sangat penting dilaksanakan oleh perusahaan dalam memasarkan produk jasa." Kegiatan promosi bukan saja berfungsi sebagai alat komunikasi antara perusahaan dengan masyarakat, malainkan juga sebagai alat untuk mempengaruhi masyarakat dalam kegiatan pembelian atau penggunaan jasa sesuai dengan keinginan dan kebutuhannya (Rambat Lupioadi dan Hamdani, 120).

Perangkat promosi yang kita kenal mencakup aktivitas periklanan, penjualan perorangan (personal selling), promosi penjualan, hubungan masyarakat (public relation-PR), informasi dari mulut ke mulut ( word of mouth), pemasaran langsung (direct marketing), dan publikasi.

Perangkat-perangkat promosi tersebut menjadi hal penting untuk di terapkan dalam sebuah Lembaga/Badan amil zakat untuk mengupayakan pengumpulan zakat yang optimal. saat ini media komunikasi yang sangatlah dekat dengan masyarakat adalah televisi, dan internet hampir keseluruhan lapisan masyarakat memiliki televisi dan berhubungan dengan internet dalam berbagai bentuk dan bahkan dalam beberapa alat telekomunikasi terdapat aplikasi membuka saluran televisi.

Dengan kemajuan teknologi yang semakin pesat seperti saat ini, sudah saatnya Lembaga/Badan pengelola zakat harus mampu bersaing untuk menunjukkan eksistensinya di masyarakat. Jika media nasional belum memumpuni sebagai media 
iklan, setidaknya lembaga zakat mampu menjangkau media televisi lokal atau radio sebagai alat iklan. Oleh sebab itu iklan dalam saluran televisi merupakan salah satu strategi promosi yang dapat di tempuh untuk meningkatkan pengumpulan zakat yang optimal.

Bagian bauran promosi yang kedua yaitu penjualan perorangan, promosi penjualan dan pemasaran langsung. Dalam konteks zakat, Lembaga/Badan pengumpul zakat haruslah mempersiapkan sumber daya yang memiliki kemampuan berinteraksi yang baik. Hal ini untuk mendukung pensosialisasian zakat ditengah-tengah masyarakat lewat Mimbar Khutbah, Ceramah, atau door to door ke berbagai rumah atau instansi. Hal ini sangat memungkinkan untuk meningkatkan pengumpulan zakat sebab calon muzakki atau masyarakat akan lebih leluasa untuk bertanya seputar zakat, jika Amil bersedia terjun langsung ke rumah atau ke instansi-instansi yang memiliki potensi zakat tentu sangat dimungkinkan terjadi komunikasi yang efektif tentang sebab-sebab belum berjalannya zakat yang dibebankan pada orang atau instansi tersebut. Dan amil harus senantiasa membantu memberikan solusi agar calon muzakki dapat menunaikan zakatnya di lembaga pengumpul zakat.

Disamping aktivitas periklanan, penjualan perorangan, promosi penjualan dan pemasaran langsung, dalam mengupayakan pengumpulan zakat yang optimal Lembaga/ Badan amil zakat harus mampu membangun hubungan masyarakat yang kuat. Hal ini dapat dilakukan dengan meminta bantuan pada tokoh-tokoh masyarakat, tengku(Istilah bagi seorang da'I atau Ustaz dalam komunitas bahasa suku Aceh) atau Ulama setempat untuk membantu mensosialisasikan pentingnya kewajiban berzakat. Hal ini tentu sangat membantu lembaga/badan Amil zakat dalam upaya mencerdaskan dan mensadarkan masyarakan terhadap kewajiban zakat. Dengan adanya bantuan dari tokoh-tokoh masyarakat atau Ulama setempat diharapkan akan terjadi proses informasi dari mulut kemulut (word of mouth).

Tidak dapat dipungkiri bahwa sifat manusia sosial memiliki kecendrungan berkelompok-kelompok dan setiap kelompok cendrung ada figur-figur yang dipercaya oleh masyarakat. Dengan adanya bantuan dari para figur-figur teladan dalam masyarakat tersebut diharapkan kesadaran berzakat akan tumbuh yang terbangun dari hasil komunikasi yang efektif dan efisien.

Hal yang ketiga yaitu: adanya publikasi dari Lembaga/Badan pengelola zakat. Publikasi merupakan hal yang penting dilakukan sebab publikasi inilah yang menjadi salah satu barometer untuk membuktikan sejauh mana Lembaga/Badan pengelola zakat tersebut dapat menjalankan amanahnya secara kredibel dan akuntabel terhadap dana umat. Publikasi ini dapat dilakukan dengan laporan mingguan, bulanan atau ta- 
hunan kepada seluruh muzakki. Adapun media yang digunakan dapat berupa iklan, majalah, buletin atau papan pengumuman di berbagai masjid.

\section{Promosi dalam perspektif Syari'ah}

Dalam perspektif Islam kegiatan pemasaran harus dilaksanakan secara jujur begitu juga dalam kegiatan promosi. Promosi suatu barang atau jasa terlebih lagi zakat harus dilaksanakan apa adanya tampa harus menyembunyikan kekurangan dari barang atau jasa tersebut, marketing dalam Islam harus didasarkan pada prinsip-prinsip syari'at Islam dan nilai-nilai spiritual. Dalam hal ini ada 4 sikap yang harus diterapkan dalam upaya menjadi seorang marketer, diantaranya yaitu (Hermawan Kartajaya dan Muhammad Syakir Sula, 2008: 120-128):

\section{a) Shiddiq (benar dan jujur)}

Seorang pemasar dalam memasarkan produknya harus menerapkan sikap shiddiq, senantiasa mengedepankan kebenaran informasi yang diberikan dan jujur dalam menjelaskan keunggulan produk-produk yang dimiliki.

b) Amanah (tepercaya,kredibel)

Amanah artinya dapat dipercaya, bertanggung jawab, dan kredibel. Seseorang pemasar haruslah memiliki sifat amanah, karena Allah menyebutkan sifat orangorang mukmin yang beruntung adalah yang dapat memelihara amanah yang diberikan kepadanya. amanah juga berarti tanggung jawab dalam melaksanakan tugas dan kewajiban yang diberikan.

c) Fathanah (cerdas)

Fathanah dapat diartikan sebagai intelektual, kecerdikan atau kebijaksanaan. Dalam bisnis, sifat jujur, benar, dan tanggung jawab saja tidak cukup. Sikap fathanah sangat diperlukan agar suatu usaha bisa lebih efektif dan efisien serta mampu menganalisis persaingan perubahan-perubahan dimasa yang akan datang.

\section{d) Thabligh ( komunikatif)}

Sifat thabligh artinya komunikatif dan argumentatif. Orang yang memiliki sifat tabligh akan menyampaikannya dengan benar (berbobot) dan dengan tutur kata yang tepat (bi al hikmah). Pemasar dalam melakukan promosi harus mampu menyampaikan keunggulan-keunggulan lembaga dengan jujur dan tidak harus berbohong menipu. 


\section{Optimalisasi Pengumpulan Zakat Dengan Metode UPZM}

Selain promosi atau sosialisasi sebagai alat yang amat penting dalam menghimpun zakat, strategi penting lainnya yang menjadi cara unik untuk memaksimalkan pengumpulan zakat yaitu dengan mengaktifkan Baitul Mal Gampong sesuai dengan amanat qanun No 10 tahun 2007 dan kemudian menjadikan masjid sebagai sentral pengumpul zakat dengan membentuk (UPZM) Unit pengumpul Zakat Masjid.

Fenomena keberhasilan masjid-masjid di provinsi Aceh dalam mengumpulkan zakat dan mendistribusikan zakat fitrah setiap menjelang hari raya 'Idul fitri harusnya menjadi peluang besar untuk mengulang kaberhasilan tersebut dalam kasus zakat mal. Secara spesifik UPMZ dapat menetapkan hari jum'at sebagai hari pengumpulan zakat, peluang ini didasari oleh setiap Muslim dibebankan kewajiban untuk melaksanakan ibadah shalat Jum'at secara berjamaah di Masjid. Dan dalam realita yang terjadi bahwa, setiap hari Jum'at masjid-masjid dipenuhi oleh para jama'ah yang jarang terjadi pada shalat fardhu lainnya. Oleh sebab itu, hal ini menjadi suatu kesempatan besar untuk mensosialisasi dan menjadikan Jum'at sebagai hari berzakat.

Dengan adanya program jum'at sebagai hari berzakat memungkinkan tercapainya penghimpunan zakat secara maksimal. Sebab, zakat akan menjadi sangat dekat dan mudah di tunaikan seperti halnya proses penunaian zakat fitrah. Dan para muzakkipun dapat merangsang masyarakat yang lain untuk ikut berzakat dan berinfaq jika mereka belum mampu berzakat. Kemudian langkah berikutnya UPZM turut membantu Baitul Mal dalam menginformasikan kepada masyarakat mengenai pengeluaran zakat yang telah dihimpun, zakat tersebut dapat dikeluarkan bagi faqir/miskin, Amil, Muallaf, gharim, fisabilillah, Ibnu sabil, dan program-program lain yang menggunakan sumber zakat seperti, sunat massal, pengajian, beasiswa dan lain-lain.

Informasi ini dapat diberitakan dengan informasi yang ditempel di papan pengumuman atau diumumkan secara langsung. Dengan adanya informasi yang jelas dan transparan maka kepercayaan masyarakat akan tumbuh dan masyarakatpun tidak meragukan lagi profesionalisme amil sebagai pengelola dana umat.

\section{SIMPULAN}

Peran zakat dalam meninggikan derajat umat harus ditangani dengan serius. Untuk menggali potensi zakat khususnya di Aceh Baitul Mal harus senantiasa menyiapkan generasi-generasi yang dapat berjuang penuh untuk kemajuan Baitul Mal. Salah satu strategi dalam menghimpun potensi zakat di Aceh yaitu dengan memaksimalisasi promosi, sosialisasi dan pengaktifan unit pengumpul zakat Masjid (UPMZ). Promosi dan sosialisasi erat kaitannya dalam membangun pemahaman dan mengarah pada 
edukasi zakat kepada masyarakat. Sedangkan pengaktifan UPMZ merupakan suatu strategi mempermudah masyarakat dalam membayar zakat.

Dengan adanya sinergitas antara promosi, sosialisasi dan pengaktifan UPMZ tentu harus didukung dengan energi para relawan-relawan muslim yang siap berkorban serta membangun profesionalisme dalam upaya pengelolaan zakat yang lebih baik.

\section{PUSTAKA ACUAN}

Qaradhawi, Yusuf. Spektrum Zakat Dalam Membangun Ekonomi Kerakyatan. Jakarta Timur : zikrul Hakim, 2005.

Qaradhawi, Yusuf. Fiqhuz Zakat. Beirut: Muassasah Risalah, 1991.

Sabiq, Sayyid. Fiqh Sunnah. Kuwait: Daar el-Bayan,1968.

Zuhaili, Wahbah. Fiqih Islam Wa Adillatuhu. Gema Insani :2011.

Idris, Safwan. Gerakan Zakat dalam Pemberdayaan Ekonomi Umat,Jakarta: Cita Putra Bangsa, 1997.

Hafifuddin, Didin. Zakat Dalam Perekonomian Modern, Jakarta: Gemalnsani, 2002.

Departemen Agama RI, Petunjuk Pelaksanaan Pemberdayaan Zakat. Jakarta: 2007. http://www.waspada.co.id diakses tanggal 11 Januari 2017

Basu Swasta dan T. Hani Handoko. Manajemen Pemasaran Analisis Perilaku Konsumen. Yogyakarta : BPFE, 1982.

Hermawan Kartajaya dan Muhammad Syakir Sula. Syari'ah Marketing. Bandung; PT Mizan Pustaka, 2008. 